\title{
DIRECT ASSIMILATION OF AMMONIUM SALTS BY PLANTS.
}

\author{
By H. B. HUTChINSON, Ph.D., and N. H. J. MILLER. \\ Rothamsted Experiment Station.
}

IT has recently been shown ${ }^{1}$ that the soil of some of the Rothamsted Grass Plots which have received ammonium salts for many years in succession has become distinctly acid and that, consequently, nitrifying organisms have become greatly reduced in numbers. Nitrification is limited to portions of soil directly in contact with the few particles of calcium carbonate still remaining in the soil. It is evident therefore that more or less of the nitrogen assimilated by the grasses must be in a form, or in forms, other than nitrate-probably mainly as ammonium salt. In view of these results it seemed desirable to obtain additional evidence of direct assimilation of ammonium salts by plants.

The question possesses a further interest in the case of leguminous plants, since whilst non-leguminous crops (whether able to assimilate ammonia or not) undoubtedly take up, under normal conditions, most of their nitrogen in the form of nitrates, we have no knowledge of the form of nitrogen appropriated by leguminous plants from their root nodules.

In 1890 , Loew ${ }^{2}$ showed that platinum black in presence of alkali produces ammonium nitrite from nitrogen and water, and suggested that assimilation of free nitrogen is accomplished in a similar manner. The examination by one of us, in 1890 , of numerous fresh nodules showed almost invariably an alkaline reaction, sometimes very marked. When this view, assigning an indirect role to the nodule organism-the production of suitable physical and chemical conditions for the union of nitrogen with the elements of water-was put forward, fixation of nitrogen apart from the nodules had not yet been observed. Recently Loew and $\mathrm{Aso}^{3}$ have suggested that ammonium nitrite is the first

1 Proc. Roy. Soc. 1908, B. 80, 196.

${ }^{3}$ Ber. 1890, 23, 1447.

3 Bull. Coll. Agric. Tokyo, 1908, 7, 567. 


\section{Direct Assimilation of Ammonium Salts by Plants}

compound produced, and that the nitrous acid is immediately reduced to ammonia. An experiment we made with beans taken from a garden, showed the presence of ammonia both in the root and in the nodules. A few grams of fresh nodules, and about the same weight of the roots from which they were taken, were extracted with 75 per cent. alcohol and the extracts distilled under reduced pressure with magnesia." The amounts of nitrogen as ammonia were as follows :-

$$
\begin{aligned}
& \text { In Roots } N .=0.016 \text { per cent. } \\
& \text { In Nodules } N .=0.043 \text { per cent. }
\end{aligned}
$$

If it should be shown that nodules generally contain more ammonia than the roots, and that ammonia is readily assimilated by leguminous plants, the results would lend some support to Loew's suggestion. In this connexion it may be mentioned that Frank (27) looked for nitrates in the nodules of peas grown in soil and failed to find any, whilst the roots showed a distinct nitrate reaction both above and below the point at which the nodules were attached. In the case of plants grown in sand free from nitrogen, no nitrates could be detected in any parts. Frank also detected the presence of asparagine in lupin and pea nodules as well as in the roots. Assuming the initial process in nitrogen fixation to be the production of an ammonium salt, it is probable that some of the ammonia would at once pass into the roots. It does not follow, however, that all the nitrogen derived from the nodules is taken up in the same form, and it seems equally possible that the asparagine found in the roots may have been partly produced in the roots themselves and partly obtained from the nodules.

Before describing the experiments on assimilation of ammonium salts it will be desirable, as the prevailing ideas on the subject are anything but clear, to show in some detail what has been already done. As, however, the number of papers on the subject is considerable, attention will be confined chiefly to the more recent experiments in which nitrification has been taken into account ${ }^{1}$.

The first experiments in which precautions were taken to avoid the possibility of nitrification were made by Pitsch (21) at Wageningen. In these experiments, which were commenced in 1885 and continued every year until 1894, various plants were grown in bumus sand contained in metal pots, holding about 30 kilos. The general method employed was first to sterilise the contents of the pots, covered with cotton wool, by

1 The earlier experiments are summarised in S. W. Johnson's How Crops Feed, New York, and references are given at the end of this paper. 
suspending in an oil bath heated at $160-180^{\circ}$. The soil was next extracted (in the pots) with water to remove nitrates, and again sterilised. Nitrogen, in the form of ammonium sulphate and sodium nitrate respectively, was added to the soil, sometimes both in larger and smaller amounts. Occasionally ammonium phosphate was also employed. Each series of experiments generally included pots which had been neither sterilised nor extracted, as well as sterilised and extracted soils without addition of nitrogen. During growth sterilised water was supplied to the soil from below. Some time (not immediately) after the conclusion of the experiments the soil was examined for nitrates and in every case nitric nitrogen was found to be absent. The results showed that whilst ammonium salts were directly assimilated, without previous nitrification, the yields obtained with nitrate were generally better, the advantage of nitrate over ammonium salts being particularly marked during the early stages of growth.

In an experiment with Oats in 1890, Pitsch found that all the soils, at the conclusion of the experiment, contained ammonia ( $N .=0.0015$ to 0.0058 per cent.), and that this nitrogen, added to the nitrogen in the plants, amounted to considerably more than was contained in the manures. It was found moreover that the nitrate plants contained more than twice as much nitrogen as was supplied in manure. So that these plants evidently drew on the soil nitrogen, probably, for the most part, in the form of ammonia, and partly as soluble humus', produced in the process of sterilisation.

In his last experiments, Pitsch shows that additions of sodium chloride to the pots manured with ammonium sulphate considerably increased the yield. It would seem to be possible that the relatively low yields obtained in most cases with ammonium salts may have been in part due to unfavourable conditions as regards the mineral constituents of the soil.

The methods employed by Pitsch seem to be as satisfactory as possible in experiments on so large a scale. It is evident that the soils were not only thoroughly sterilised, but that the condition of sterilisation was maintained. But although the results show that the different plants grew in absence of nitrates, they fail to show that the nitrogen assimilated was exclusively in the form of ammonia.

In 1887, Frank (22) grew beans and sunflowers in water-cultures containing nitrogen as ammonium salt and as nitrate. The solutions

${ }^{1}$ Compare H. W. Wiley, Landwo. Versuchs-Stat, 1898, 49, 193. 


\section{Direct Assimilation of Ammonium Salts by Plants}

were not sterilised, and the only precaution to avoid nitrification was to add calcium in the form of chloride instead of as carbonate. The solutions were found, however, to be free from nitrates and to contain ammonia at the end of the experiment. The beans grew fairly well when supplied with an ammonium salt, and the stems were found to be free from nitrates.

Müntz, in 1889 (24) experimented with beans, kidney beans, maize, barley and hemp which were grown in soil which was first extracted and then heated at $100^{\circ}$. The seeds were sterilised by dipping for a moment into boiling water, and the pots were kept in cases ("véritables cages de Tyndall") provided with openings, covered with cloth, to render the air passing in free from germs. At the conclusion of the experiment the soils were found to be free from nitrates. The different plants assimilated 49 to $915 \mathrm{~m} . \mathrm{g}$. of nitrogen, probably in the form of ammonia. There is, however, no proof that nitrification had been entirely absent. If the ammonium salts had been only slowly, and perhaps locally, nitrified all traces of nitrates might have been removed by the plants. In Pitsch's experiments as already mentioned, the soils were left for some time after the plants were taken out before being examined for nitrates, so as to allow time for further nitrification in the event of nitrifying organisms being present.

Griffiths (25), almost at the same time as Müntz, grew beans in sterilised water-cultures, with ammonium sulphate as source of nitrogen. The seeds were sterilised by remaining half-an-hour in copper sulphate solution, and the jars containing the solutions were placed under large bell-jars the openings of which were closed with cotton wool. The plants grew remarkably well for four weeks, and reduced the amount of nitrogen in the solution from 0.05 to 0.027 per cent.; no nitrate could be detected.

The next experiments, by Bréal (28), were made with Poa annua. Tufts of the grass growing in soil were dug up, and the roots washed until free from soil and then placed in water. New roots were soon produced, whilst the original roots left off growing. After cutting off the old roots the plants were supplied with dilute solutions of ammonium sulphate. It was found that after 24 hours all the ammonia had been taken up. In these experiments sterilisation was unnecessary as the time was too short for nitrification to occur.

Kinoshita (29), and, subsequently Suzuki (30), grew seedlings of various plants for short periods in solutions of ammonium salts and sodium nitrate, in order to compare the amounts of asparagine pro- 
duced. It was found that ammonium salts are rapidly converted into asparagine, whilst nitrates tended to accumulate, and, during the short time the experiment lasted, generally failed to increase the amount of asparagine. The production of asparagine is promoted by the presence of sugar, and in absence of sugar, or other suitable material, it was found that ammonia may accumulate in the plants and eventually cause injury.

In 1898, Mazé (32) grew maize in sterilised water-cultures containing anmonium sulphate and sodium nitrate respectively; calcium carbonate 0.2 per cent. was added. Two months afterwards the plants were taken up, and it was found that the ammonium sulphate solutions still contained ammonia, and that no nitrate was produced. The plants grew about equally well in the two solutions. In later experiments (33), culture solutions were employed containing both forms of nitrogen in different proportions. The results showed that when the relations of ammonium sulphate to sodium nitrate were $1: 2$ or $1: 4$ the whole of the ammonia was utilised whilst some nitrate remained in the solutions.

Kossowitsch (35) experimented with peas in sterilised sand-cultures. Calcium carbonate was present in addition to the usual minerals, and the ammonium salt was added gradually during growth. The results showed that ammonium sulphate and sodium nitrate were equally suitable as sources of nitrogen. The solutions and sand to which ammonium sulphate had been added were found at the end of the experiment to be free from nitrates and nitrifying organisms; in some cases, however, it was discovered that other micro-organisms were present, and in some moulds.

Gerlach and Vogel (37) found that maize plants, grown in sterilised soil manured with ammonium sulphate, contained more nitrogen $(0.418$ gram.) than similar plants grown in the same soil without nitrogen; the soils were found to be free from nitrates at the conclusion of the experiment.

Krüger (38) made a large number of experiments with various plants grown in a sterilised mixture of soil and sand. Sterilisation was effected by heating the pots in steam for one hour on 6 days; the seeds were sterilised with mercuric chloride. At the conclusion of the experiment, the soils were examined and those containing nitrate excluded. The conclusion is drawn that ammonium salts and nitrates are equally suitable for mustard, oats and barley; that ammonia is, if anything, better than nitrates for potatoes, whilst for mangolds nitrates are decidedly better than ammonium salts. 


\section{Direct Assimilation of Ammonium Salts by Plants}

The last experiments to be described are those of Ehrenberg (39), who grew oats in sterilised soil, and in sterilised sand, employing seeds sterilised with mercuric chloride. Nitrogen was added in the forms of amınonium sulphate and sodium nitrate in sterilised solutions after the sand and soil had been sterilised. Calcium carbonate was present. The results of both series were negative as regards ammonium salts, the plants failing to grow, and the conclusion is drawn that nitrification is essential to the growth of higher plants, at any rate in the case of soils of slight absorptive power. When, however, the amounts of ammonium salts employed are considered in relation to the amount of water present, it will be seen that the injurious effects were probably due to too great concentration. The sand ( 5 kilos. per pot) contained 10 per cent. of water, or 500 c.c., and the amount of ammonium sulphate present was 1.4 gram or 2.8 grams per litre. In the soil ( 3.8 kilos.) the amount of water was 20 per cent., or 760 c.c., and this contained 1.8 gram of ammonium sulphate per litre. It has been shown by Mazé (loc. cit.), that even 1 per thousand of ammonium sulphate is very injurious ${ }^{1}$, whilst in the experiment just described the amounts were nearly twice, or nearly three times, as high supposing the salt to be equally distributed (which was probably not the case), and a good deal higher, locally, if not evenly distributed. It is stated that on turning out the pots a distinct odour of ammonia was noticed.

The results of all the experiments described above may be summarised as follows. The results of Griffiths and Mazé seem to prove conclusively that beans and maize assimilate ammonium salts as readily as nitrates. The same may be said of Kossowitsch's experiments with peas, for although sterilisation was imperfectly maintained, vitrifying organisms were completely excluded. Bréal's results may also be considered to establish the utilisation of ammonia (by Poa annua). The results obtained by Pitsch, Müntz, Gerlach and Vogel, and Krüger indicate that the various plants employed are able to grow in absence of nitrate-not with absolute certainty as regards Müntz's experiments-but fail to prove that ammonia was the sole source of nitrogen.

\section{ExPERIMENTAL.}

Seed Sterilisation. In order to obtain vigorous seedlings free from nitrifying and other organisms, whose presence would vitiate the results, some preliminary experiments on seed sterilisation were made. The

1 See also Coupin, Rév. Gén. Bot. 1900, 12, 177, and Suzuki, Bull. Coll. Agric. Tokyo, $1894-7,2,265$. 
usual method, that of simply soaking the seeds in mercuric chloride solution, was found to be unsatisfactory owing to the persistence with which occasional air-bubbles remain on or inside the seed, and thus prevent complete sterilisation. A greater amount of success was attained by subjecting the seeds to a preliminary treatment with ether or alcohol and subsequent transference to the disinfectant solution. The most satisfactory results, however, were obtained by treating the seeds in a warm mercuric chloride solution after the removal of any air-bubbles by means of a vacuum pump; for this purpose the following apparatus was used.

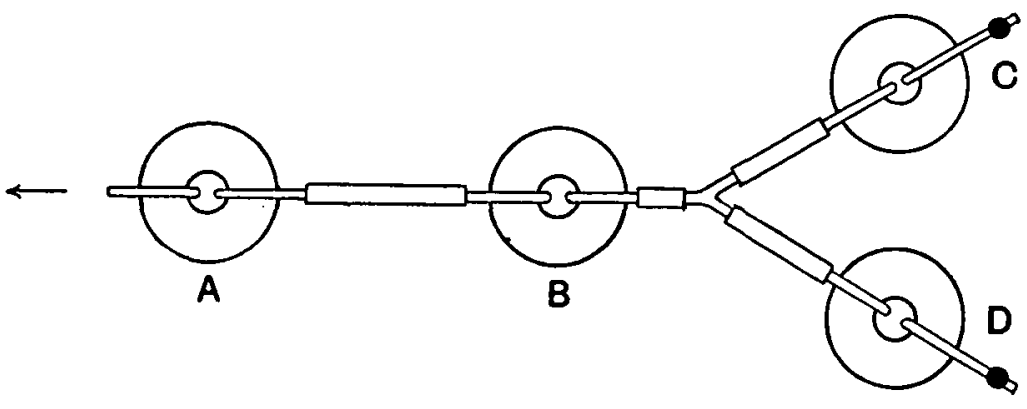

Fia. 1.

A stout-walled glass flask $B$, bearing a rubber cork with two glass tubes, was attached on the one hand to a safety flask $A$, and on the other, by means of a three-way tube, to two glass flasks of about 1 litre capacity $C$ and $D$. $C$ was filled with a 0.25 per cent. solution of mercuric chloride, $D$ with distilled water. The whole apparatus was then sterilised in the autoclave at $125^{\circ} \mathrm{C}$. for half an hour, and after being allowed to cool to $40^{\circ} \mathrm{C}$, the flask $A$ was attached to a vacuum pump. Seeds of approximately equal size were then placed in the flask $B$ by means of a funnel-to prevent contact between the seeds and the neck of the flask-and mercuric chloride was drawn by means of the pump into $B$ from $C$. The connecting tube was then closed with a screw-clip and $B$ was evacuated until the solution began to boil. By this means all air-bubbles present on the surface of the seed or between the cotyledons and the seed-coat were withdrawn, and on releasing the vacuum the disinfectant solution was able to act on all portions of the seed.

Sterilisation was allowed to proceed for 3-4 minutes, and after $B$ had been inverted and the disinfectant withdrawn by means of the 


\section{Direct Assimilation of Ammonium Salts by Plants}

pump, sterilised water was allowed to flow in from $D$ and the seeds well washed in 2-3 changes of water. They were then transferred to Petri dishes and a sterilised 1.25 per cent. solution of agar was poured in; solidification of the medium occurred in a few minutes, the plates were inverted and placed in the incubator at $20^{\circ} \mathrm{C}$.

At the end of 3-4 days, the majority of the seeds had germinated and formed roots $1-1 \frac{1}{2}$ inches in length, and if sterile, remained quite free from mould or bacterial growth, and were then transferred to sterile wide glass test-tubes containing 10 c.c. distilled water over which a small plug of cotton wool had been placed. On this cotton wool the seedlings were allowed to grow until the shoot was approximately 3 inches long, and if they failed to show any subsequent infection, were then carried over to the culture bottles at the end of $7-8$ days.

Culture Bottles. Many forms of apparatus have been suggested for the cultivation of plants under sterile conditions; but the majority are either too complicated or do not allow sufficient facilities for the exclusion of micro-organisms at all stages of the plant's growth. The apparatus used in these experiments has the advantage of being comparatively simple, is compact enough to allow of sterilisation in any ordinary autoclave, and may be used either for soil-, sand-, or watercultures.

For the reception of the plant a three-necked Woulf's bottle $A$ of $750-1500$ c.c. capacity was taken, and rubber corks were placed in each of the side necks. One of the corks held a straight glass tube which had at its upper end a small adapter $B$ filled with cotton wool, while the lower end almost touched the bottom of the bottle; this tube served to filter the air used for aerating the bottle from time to time. The other cork held a short glass tube bent at right angles which was connected to a Pasteur-Hansen flask $C$, filled with distilled water, in order that the culture solution in the Woulff's bottle could be kept to the same level throughout the course of the experiment. A few drops of concentrated sulphuric acid were placed in the side tube $D$. In many cases the flask $C$ was attached to two or three Woulff's bottles by means of three- or four-way glass tubes. The middle neck of the culture bottle was firmly plugged with cotton wool and the whole apparatus heated in the steam steriliser at $99^{\circ}$ for three hours. As soon as the sterile seedlings had formed shoots about $2 \frac{1}{2}-3$ inches in length they were taken from the test-tubes with sterilised forceps and the roots introduced through the middle neck of the Woulff's bottle 
until they reached the culture solution; the shoot was then tightly plugged round with non-absorbent cotton wool, in order to keep the seedling in position.

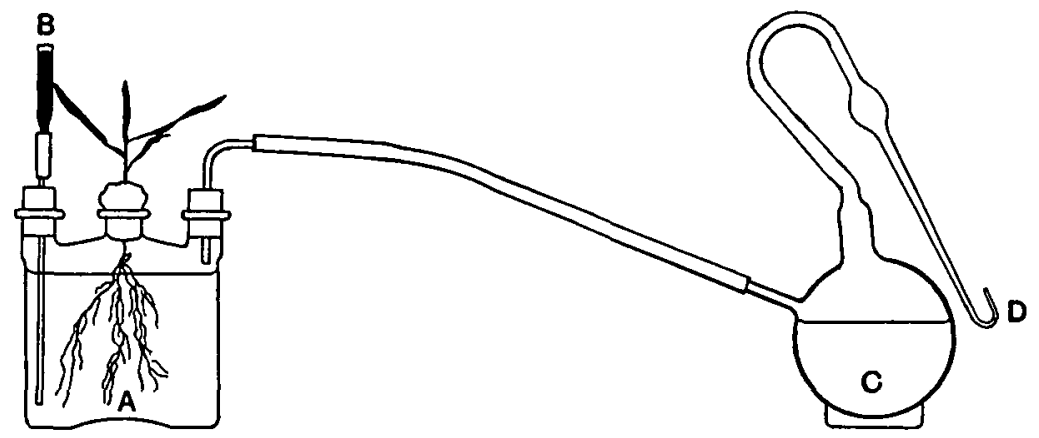

Fig. 2.

Direct Assimilation of Ammonium Salts by Plants.

Series I. Wheat grown in Sand. The seeds were sterilised in 0.25 per cent. solution at $45^{\circ} \mathrm{C}$. and sown on agar plates. Germination was quite normal and after 3-4 days the seedlings were transferred to sterilised test-tubes and allowed to grow for a further period of 6-7 days. On May 21st, 1908, they were carried over to 10 Woulff's bottles containing the following amounts of sand and nutrient salts.

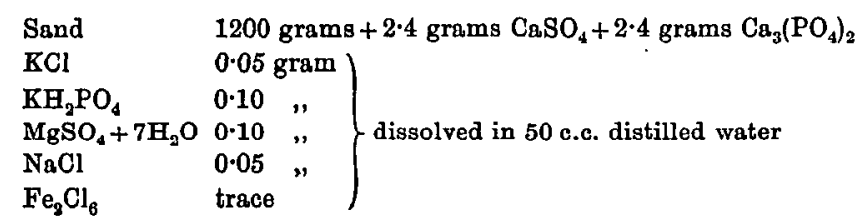

Bottles $1-3$ and $7-9$ received in addition 6 grams of $\mathrm{CaCO}_{3}$. The bottles and the Pasteur-Hansen flasks were sterilised in the autoclave at $125^{\circ} \mathrm{C}$. for half an hour, and after cooling down a solution of ammonium sulphate $=21.98$ mgms. of nitrogen was added to bottles $1-9$, and sodium nitrate $=2074 \mathrm{mgms}$. to bottle 10 .

At the time of transferring the young sterile plants bottles $7-9$ were inoculated with a culture of nitrifying organisms, and to all the bottles 100 c.c. distilled water was added from the Pasteur-Hansen flask. From time to time the bottles were weighed and the losses made up by adding more water, and aeration was carried out every $4-5$ days. 


\section{Direct Assimilation of Ammonium Salts by Plants}

The plants in Nos. 7-10 grew quite vigorously and possessed a dark green colour; Nos. $1-3$ were also good, while $4-6$ were stunted, No. 6 especially being very poor and censing to grow after 12-14 days. This is shown in the table by the slight amount of dry matter formed and of nitrogen assimilated.

The average amount of nitrogen in each seed was $0.71 \mathrm{mgm}$.

TABLE I. Wheat in Sand Cultures.

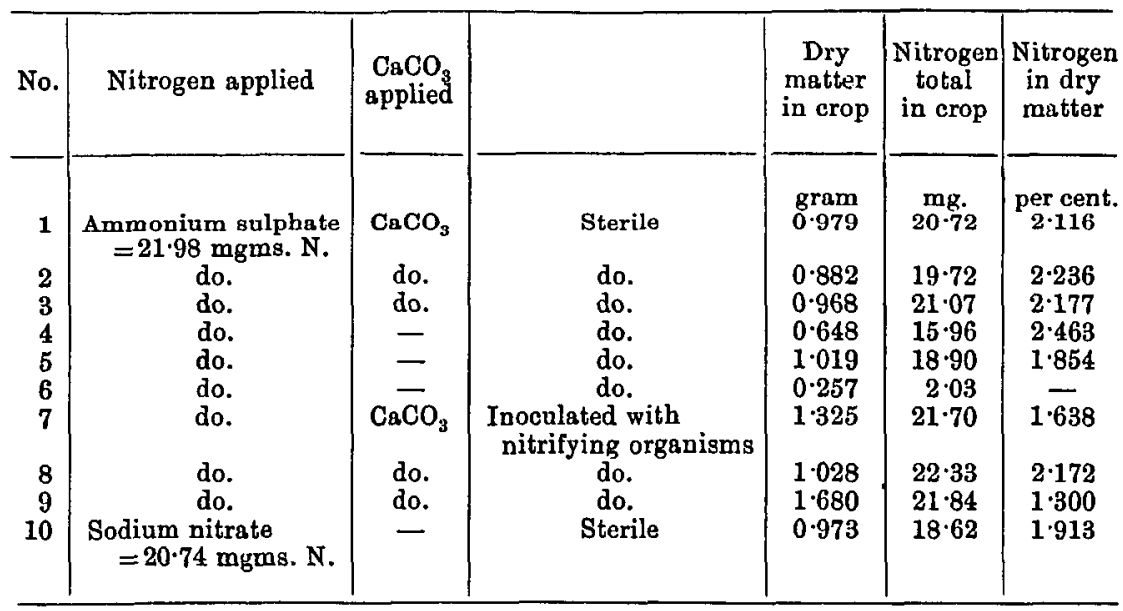

At the close of the experiment portions of the sand in each bottle were carried over to flasks containing Omelianski's solution and showed the absence of nitrifying organisms in bottles 1-6.

Series II. Wheat grown in Water Culture. This series was carried out in order to corroborate the results of the previous experiments. The treatment of the seed and seedlings was in every respect similar to that of the foregoing series, and the seedlings were transplanted when about $7 \mathrm{~cm}$. high. Woulf's bottles of $850 \mathrm{c.cm}$. capacity were fitted with aeration tubes and Pasteur-Hansen flasks and were filled with the following solution:-

$$
\left.\begin{array}{ll}
\mathrm{MgSO}_{4}+7 \mathrm{H}_{2} \mathrm{O} & 0.5 \mathrm{gram} \\
\mathrm{CaSO}_{4} & 0.5 " \\
\mathrm{KH}_{2} \mathrm{PO}_{4} & 0.5 " \\
\mathrm{NaCl} & 0.25 " \\
\mathrm{KCl} & 0.25 " \\
\mathrm{Fe}_{2} \mathrm{Cl}_{6} & 10 \text { c.c. of a } 1 \% \text { solution }
\end{array}\right\}+1000 \text { c.c. distilled water }
$$

To Nos. 3 and 4, 5 and 6, 2 grams $\mathrm{CaCO}_{3}$ was added. After the bottles had been sterilised in the autoclaves, 10 c.c. of a sterile solu- 
tion of ammonium sulphate containing 21.54 mgins. N. was added, Nos. 5 and 6 were inoculated with nitrifying organisms from a liquid culture, and the sterile seedlings introduced on July 4th in a slightly etiolated condition.

From the commencement of the experiment growth in Nos. 1 and 2 was very slow, the root growth especially being very poor. During the first 3-4 weeks, Nos. 3 and 4 grew fairly rapidly and an abundance of roots was formed. These however were not equally distributed throughout the culture solution but remained in a very coiled mass near the surface of the liquid. This marked toxic effect persisted for $4-5$ weeks and was subsequently followed by an even ramification of the roots in all portions of the culture solution.

On August 6th, the plants in Nos. $1-5$ appeared healthy, while that in No. 6 remained etiolated for 2-3 weeks and finally died off. A marked distinction could be seen in the colour of the plants, that in No. 5 being of a much darker green than the others. From August 15th the plant in No. 4 began to grow much more vigorously, and the adoption of a darker colour seemed to indicate infection with nitrifying organisms. This would seem to be supported by the fact that both the dry matter is higher and the percentage of nitrogen lower, than in the other ammonium sulphate bottles.

TABLE II. Wheat growing in Water Cultures.

\begin{tabular}{|c|c|c|c|c|c|}
\hline No. & & & $\underset{\text { matter }}{\text { Dry }}$ & $\begin{array}{c}\text { Nitrogen } \\
\text { total in } \\
\text { crop }\end{array}$ & $\begin{array}{c}\text { Nitrogen } \\
\text { in dry } \\
\text { matter }\end{array}$ \\
\hline $\begin{array}{l}1 \\
2 \\
3 \\
4 \\
5\end{array}$ & $\begin{array}{c}\text { No } \mathrm{GaCO}_{3} \\
\text { do. } \\
\mathrm{CaCO}_{3} 2 \text { grams } \\
\text { do. } \\
\text { do. }\end{array}$ & $\begin{array}{c}\text { Sterile } \\
\text { do. } \\
\text { do. } \\
\text { do. (?) } \\
\text { Inoculated with nitrifying organisms }\end{array}$ & $\begin{array}{l}\text { gram } \\
0 \cdot 284 \\
0 \cdot 239 \\
0 \cdot 387 \\
0 \cdot 872 \\
1 \cdot 208\end{array}$ & $\begin{array}{r}\text { mg. } \\
7 \cdot 42 \\
6 \cdot 16 \\
13 \cdot 02 \\
14 \cdot 28 \\
17 \cdot 50\end{array}$ & $\begin{array}{c}\text { per cent. } \\
1.866 \\
1.841 \\
2.403 \\
1.169 \\
1.035\end{array}$ \\
\hline
\end{tabular}

Series III. Peas in Water Cultures. The cultures were made in Woulff's bottles holding about 1200 c.c. water in which the following umounts of the different salts were dissolved:-

$\begin{array}{ll}\mathrm{CaSO}_{4} & 0.5 \mathrm{gram} \\ \mathrm{MgSO}_{4}+7 \mathrm{H}_{8} \mathrm{O} & 0.5 \quad " \\ \mathrm{KCl} & 0.25 ", \\ \mathrm{NaCl} & 0.25 " \\ \mathrm{KH}_{2} \mathrm{PO}_{4} & 0.5 \quad " \\ \left(\mathrm{NH}_{4}\right)_{2} \mathrm{SO}_{4} & 0.389 " \\ \text { or } \mathrm{NaNO}_{3} & 0.5 " \\ \mathrm{Fe}_{3} \mathrm{Cl}_{6} & \text { trace }\end{array}$




\section{Direct Assimilation of Ammonium Salts by Plants}

The solutions were sterilised by heating for an hour at $100^{\circ}$ on four successive days. Calcium carbonate ( 2 grams) was sterilised, and added to each bottle at the same time that the seedlings were put in. The bottles were arranged in sets of three, each set being connected with a Pasteur flask filled with sterilised distilled water. One set received sodium nitrate, and one ammonium sulphate, and there were two similar sets which received 2 grams of dextrose in addition, so that there were altogether twelve bottles as follows:-

$$
\begin{aligned}
& \text { I. Nos. 1, 2, } 3 \text { Sodium nitrate } \\
& \text { II. " } 4,5,6 \quad \text { "dextrose } \\
& \text { III. " } 7,8,9 \text { Ammonium sulphate } \\
& \text { IV. " } 10,11,12 \quad " \text { "dextrose }
\end{aligned}
$$

The seedlings were put in on June 1, and the plants taken up on July 20, 1908. With the exception of No. 8, which failed at an early date, all the plants grew normally and showed no appreciable differences under the different conditions. Towards the end of the experiment No. 6 suddenly lost its green colour owing to the development of a mould which quickly appropriated all the available nitrogen. All the other plants remained perfectly healthy to the end.

On taking up the plants it was found that the solutions of Nos. 3, 4,5 and 12 were infected. The remaining ammonium solutions were free from nitrites and nitrates as well as from nitrifying organisms. In the following table are set out the amounts of dry produce, the nitrogen

\begin{tabular}{|c|c|c|c|c|c|c|c|}
\hline No. & & $\begin{array}{c}\text { Dry } \\
\text { matter }\end{array}$ & $\left\{\begin{array}{c}\text { Nitrogen } \\
\text { in dry } \\
\text { produce }\end{array}\right.$ & $\begin{array}{c}\text { Nitrogen } \\
\text { in } \\
\text { plants, } \\
\text { total }\end{array}$ & $\begin{array}{c}\text { Nitrogen } \\
\text { as } \mathrm{NH}_{3} \\
\text { in solu- } \\
\text { tion }\end{array}$ & $\begin{array}{c}\text { Nitrogen } \\
\text { as } \mathrm{N}_{2} \mathrm{O}_{5} \\
\text { in solu- } \\
\text { tion }\end{array}$ & $\begin{array}{c}\text { Total } \\
\text { nitrogen } \\
\text { in solu- } \\
\text { tion }\end{array}$ \\
\hline $\begin{array}{l}1 \\
2\end{array}$ & Nitrate ... & $\begin{array}{l}\text { grams } \\
3 \cdot 194 \\
2 \cdot 406\end{array}$ & $\begin{array}{c}\text { per cent. } \\
2 \cdot 764 \\
3 \cdot 061\end{array}$ & $\begin{array}{l}\text { gram } \\
0.088 \\
0.074\end{array}$ & $\begin{array}{c}\text { gram } \\
0 \\
0\end{array}$ & $\begin{array}{l}\text { gram } \\
\text { trace } \\
0.007\end{array}$ & $\begin{array}{c}\text { gram } \\
- \\
-\end{array}$ \\
\hline $\begin{array}{l}7 \\
9\end{array}$ & Ammonium sulphate & $\begin{array}{l}3 \cdot 222 \\
0 \cdot 860\end{array}$ & $\begin{array}{l}2 \cdot 819 \\
5 \cdot 306\end{array}$ & $\begin{array}{l}0.091 \\
0.046\end{array}$ & $\begin{array}{l}0.003 \\
0.032\end{array}$ & $\begin{array}{l}0 \\
0\end{array}$ & $\begin{array}{l}0.004 \\
0.040\end{array}$ \\
\hline $\begin{array}{l}10 \\
11\end{array}$ & $\begin{array}{l}\text { Ammonium sulphate } \\
+ \text { dextrose } \ldots . . . . . .\end{array}$ & $\begin{array}{l}2 \cdot 241 \\
1 \cdot 330\end{array}$ & $\begin{array}{l}3 \cdot 859 \\
4 \cdot 679\end{array}$ & $\begin{array}{l}0.086 \\
0.062\end{array}$ & $\begin{array}{l}0.002 \\
0.018\end{array}$ & $\begin{array}{l}0 \\
0\end{array}$ & $\begin{array}{l}0.007 \\
0.022\end{array}$ \\
\hline
\end{tabular}
in the produce and in the solutions of Nos. 1, 2, 7, 9, 10 and 11.

Table III. Peas growing in Water Cultures.

* Including any nitrogenous matter in suspension.

The small amount of growth in No. 9 is due to the failure of the original seedling; the new plant was consequently a few days behind 
the others. The number of pods produced by the plants was-(1) 4, (2) 5 , (7) 3, (10) 2 , and (11) 2 .

Additions of dextrose had no appreciable effect, probably owing to the presence in the seedlings of sufficient available non-nitrogenous material for the production of asparagine from the small amount of ammonium salt employed.

The results of the three series of experiments show that ammonium sulphate is directly assimilated by wheat and peas and that, in the case of peas, there was no difference between the plants supplied with ammonium salt and those which had sodium nitrate. The wheat plants, however, showed a decided preference for nitrogen in the form of nitrate.

\section{Percentage of nitrogen in plants manured respectively with Ammonium Salts and Nitrates.}

Reference to Tables I, II, and III, will show that in each case in which nitrogen was applied as ammonium salts, the dry matter of the plants contained higher percentages of nitrogen than when sodium nitrate was employed. Mazé (loc. cit.), in his water culture experiments, obtained similar indications, the percentages of nitrogen being as follows:-

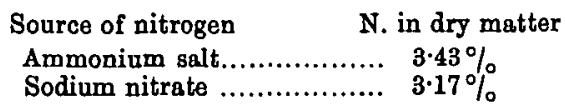

TABLE IV. Percentage of Nitrogen in the Mixed Herbage of the Rothamsted Grass Plots.

\begin{tabular}{|c|c|c|c|c|}
\hline \multirow{2}{*}{ Plot } & \multirow{2}{*}{\multicolumn{2}{|c|}{ Manuring }} & \multicolumn{2}{|c|}{ Nitrogen per cent. } \\
\hline & & & $1856-73$ & $1901-5$ \\
\hline $\begin{array}{r}14 \\
9 \\
11 \\
5\end{array}$ & 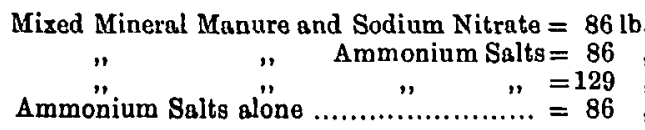 & $\begin{array}{l}\text { N. per acre } \\
" \quad " \\
" \quad " \\
" \quad "\end{array}$ & $\begin{array}{r}* 1 \cdot 31 \\
1 \cdot 55 \\
+1 \cdot 74 \\
2 \cdot 16\end{array}$ & $\begin{array}{l}1 \cdot 39 \\
1.52 \\
1 \cdot 66 \\
-\end{array}$ \\
\hline
\end{tabular}

* $1858-73$.

Pitsch also shows (loc. cit.) that in the great majority of cases the ammonia plants contain higher percentages of nitrogen than the nitrate plants. Further confirmation is afforded by a comparison of the per- 


\section{Direct Assimilation of Ammonium Salts by Plants}

centages of nitrogen in the mixed herbage from the Rothamsted grass plots, which receive their nitrogen in the form of ammonium salts and as nitrates respectively (see Table IV, p. 191).

Whilst it cannot be assumed that the whole of the nitrogen of the ammonia plots is taken up in the form of ammonia, the results as set out in the above table increase the probability that much, at any rate, of the nitrogen of the crop of plots 5,9 and 11 is assimilated in its original form.

An explanation of the high nitrogen percentages seems to be afforded by Suzuki's results (loc. cit.), which showed that ammonium salts are rapidly converted by the plants into asparagine, and so give rise to conditions favourable to renewed absorption, whilst nitrates tend to accumulate and thus check further diffusion from outside. It would seem possible that the highly nitrogenous character of leguminous plants may have been acquired as a result of long continued nutrition with nitrogen, supplied from the root-nodules in a form which lends itself to more rapid production of proteids than is possible when practically the whole of the nitrogen is taken up as nitrates, as is the case with non-leguminous crops.

\section{Conclusions.}

Agricultural plants of various kinds can produce normal growth when supplied with nitrogen in the form of ammonium salts under conditions which exclude the possibility of nitrification. Some plants grow equally well with ammonium salts or nitrate as source of nitrogen. Other plants, while assimilating ammoniacal nitrogen in the absence of nitrates, appear to prefer nitrates. It is less certain whether ammonium salts can ever produce better final results than nitrates although we have indications that this may be the case.

Lehmann (17) found that whilst buckwheat failed to grow well with ammonium salts, maize did far better with this form of nitrogen than with nitrates during the first period of growth. Later on the nitrate plants recovered, and the ammonia plants became unhealthy, "ein Bild des Jammers." Kellner (19) showed that paddy rice also prefers ammonium salts to nitrates to commence with, and that nitrates are better than ammonium salts for the later growth. The best results of all were obtained when both forms of.nitrogen were employed together. 
JOURNAL OF AGRICULTURAL SCIENCE. Vol. III. No. 2.

PLATE XIV

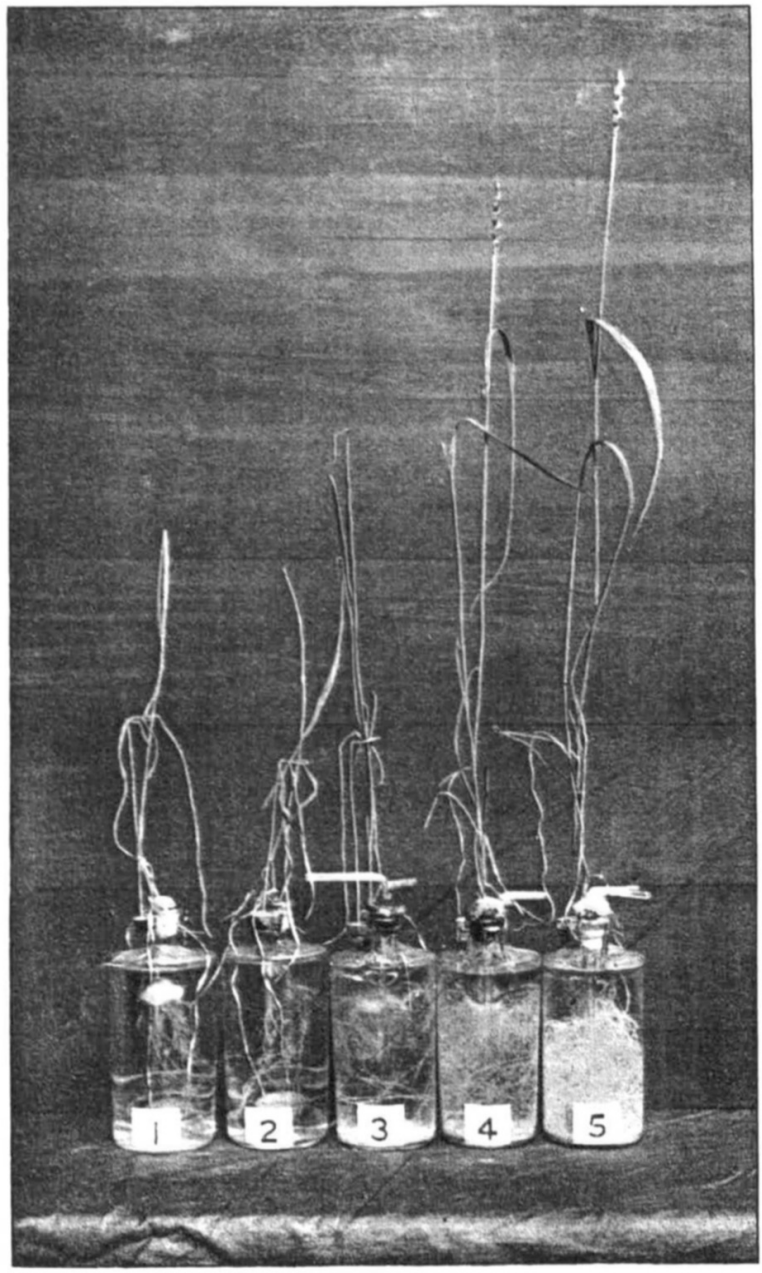

Wheat plants in water-cultures with ammonium salts. 
Plants which take up nitrogen exclusively in the form of ammonium salts generally contain very distinctly higher percentages of nitrogen than when supplied with nitrates. The question arises whether the high percentages of nitrogen in leguminous plants may be due to the nitrogen-or most of it-being assimilated in a form more suited to the rapid production of proteids than nitrate.

\section{REFERENCES.}

1. Bodchardat, A. De l'actiou des sels ammoniacaux sur les végétaux. Compt. rend. 1843, 16, 322-324.

2. VILLe, G. Quel est le rôle des nitrates dans l'economie des plantes. Compt. rend. 1856, 42, 679-68:3; 43, 612-616.

3. Cameron, C. A. On urea as a direct source of nitrogen. Rep. Brit. Assoc. 1867; and Chemistry of Agriculture, Dublin, 1857.

4. KNop, W. Landw. Versuchs-Stat. 1859, 1, 3, and 1860, 2, 65.

5. Stohmasi, F. Henneberg's Jour. f. Landw. 7, 1 ; and Annalen, 1862, 121, 323.

6. Hellrieger, H. Ann. d. Landw. 1863, 7, 53, and 8, 119.

7. Rattengerg, F. und Kühn, G. Henneberg's Jour. f. Landw. 9, 107.

8. Birner, H. und LuCanos, B. Wasserculturversuche mit Hafer. Landw. Versuchs-Stat. 1866, 8, 128.

9. BEYER, A. Einige Beobachtungen bei den diesjährigen Vegetationsversuchen in wässrigen Lösungen. Landwo. Versuchs-Stat. 1867, 9, 480.

10. - Versuche über die Bedeutung des Ammoniaks, des Harnstoffes und der Hippursïure als stickstoflieferndes Materiel. Ibid. 1869, 11, 267.

11. Kürn, G. Notiz über das Ammoniak als pflanzlichen Nährstoff. Ibid. 1867, $9,167-168$.

12. HaגPE, W. Ueber die Assimilation von Harnstoff und Ammoniak durch die Pflanzen. Ibid. 1867, 9, 49 and 157.

13. - Vegetationsversuche mit Ammoniaksalzen, Harnsäure, Hippursäure und Glycocoll als Nahrungsmittel der Pflanzen. Ibid. 1868, $10,176$.

14. WatNER, P. Vegetntionsversuche über die Stickstoffernährung der Pflanzen. Inareg. Diss. Göttingen, 1869; and Landw. Versuchs-Stat. 1869, 11, 287.

15. Scrloesina. Sur l'absorption de l'ammoniaque de l'air par les végétaux. Compt. rend. 1874, 78, 1700-1703.

16. MAYER, A. Ueber die Aufnahme von Ammoniak durch oberirdische Yflanzentheile. Landw. Versuchs-Stat. 1874, 17, 329-397.

17. Lemanan, J. Ueber die zur Ernähruug der Pflanzen geeigneste Form des Stickstoffs. Bied. Centr. 1875, 7, 403-409.

18. WErN, E. Untersuchungen über die Form in welcher der Stickstoff den Kulturpflanzen zu reichen ist. Bied. Centr. 1882, 11, 152-154; from Zeits. landw. Ver. Baiern. 1881, 299-321.

19. Kellner, O. und Sawano, J. Agriculturstudien über die Reiscultur. Landro. Versuchs.Stat. 1884, 30, 18-41. 


\section{Direct Assimilation of Ammonium Salts by Plants}

20. HARz, C. O. Beiträge zur Stickstoffernährung einiger Kulturpflanzen. Jahresber. $k$. Thierarzneischule, München, 1885, 86, 127-162.

21. PIтsch, O. Versuche zur Entscheidung der Frage, ob salpetersäure Salze fuir die Entwickelung unserer landwirtschaftlichen Kulturgewächse unentbehrlich sind oder nicht. Landw. Versuchs-Stat. 1887, 34, 217-258; 1893, 42, 1-95; and [with J. vaN HAARST] 1896, 46, 357-370.

22. Frank, A. B. Ueber Ursprung und Schicksal der Salpetersäure in der Pflanze. Ber. deut. bot. Ges. 1887, 5, 47-54.

23. - Untersuchungen über die Ernährung der Pflanze mit Stickstoff und über den Kreislauf desselben in der Landwirthschaft. Landw. Jahrb. 1888, $17,421$.

24. Müntz, A. Sur le rôle de l'ammoniaque dans la nutrition des végétaux supérieurs. Compt. rend. 1889, 109, 646-648.

25. Grifriths, A. Direct absorption of arnmoniacal salts by plants. Chem. News, $1891,64,147$.

26. PAGNodr, A. Sur l'emploi de l'azote comme engrais dans les deux formes nitrique et ammoniacal. Ann. Agron. 1891, 17, 274-283.

27. Frank, A. B. Die Assimilation freien Stickstoffs bei den Pflanzen in ihrer Abhängigkeit von Species, von Ernährungsverhältnissen und von Bodenarten. Landw. Jahrb. 1892, 21, 1-44.

28. Bráal, E. Contribution à l'étude de l'alimentation azotée des végétaux. Ann. Agron. 1893, 19, 274-293.

29. Kinoshita, Y. On the Assimilation of Nitrogen from Nitrates and Ammonium Salts by Phaenogams. Bul. Coll. Agric. Tokyo, 1894-7, 2, 200-202.

30. SozUKI, U. On the formation of asparagine in plants under different conditions. Bul. Coll. Agric. Tokyo, 1894-7, 2, 409-457.

31. Müntz, A, Recherches sur l'intervention de l'ammoniaque de l'atmosphère dans la nutrition végétale. Ann. Sc. Agron. 1896, II. 2, 161-214.

32. MAzE, $P$. L'assimilation de l'azote nitrique et de l'azote ammoniacal par les végétaux supérieurs. Compt. rend. 1898, 127, 1031-1033.

33. - Recherches sur l'influence de l'azote nitrique et de l'azote ammoniacal sur le developpement du Maïs. Ann. Inst. Pasteur, 1900, 14, 26-45.

34. Grosse-Boнle, H. Beiträge zur Frage der Selbstreinigung der Gewässer. Inaug. Diss. (Münster) Arnsberg, 1900. [Also published by J. König, Zeits. Untersuch. Nährungs- u. Genussmittel, 1900, 3.]

35. Kossowitsch, P. Ammoniaksalze als unmittelbare Stickstoffquelle für Pfanzen. J. exper. Landw. 1901, 2, 635.

36. Trebodx, O. Zur Stickstoffernährung der grünen Pflanzen. Ber, deut. bot. Ges. 1904, 22, 570-572.

37. Gerlach, M. und Voger, J. Ammoniakstickstoff als Pflanzennahrstoff. Centr. Bakt. Par. 1905, II. 14, 124-138.

38. KRÜGER, W. Ueber die Bedeutung der Nitrifikation für die Kulturpflanzen. Landro. Jahrb.. 1905, 34, 761.

39. Errenberg, P. Die Bewegung des Ammoniakstickstoffs in der Natur. Mitt. Landw. Inst. kgl. Univ. Breslau, 1907, 4, 47-300. 